\title{
Recovery of Salmonella Gallinarum in the Organs of Experimentally-Inoculated Japanese Quails (Coturnix coturnix)
}

http://dx.doi.org/10.1590/1516-635x1703281-286

\section{-Author(s)}

Rocha e Silva RC

Cardoso WMv

Teixeira RSC ${ }^{\mathrm{V}}$

Horn RV'

Cavalcanti CM"II

Almeida CPII

Sampaio FPIV

Albuquerque $\mathrm{AH}^{\prime}$

Lopes ES'

Gomes Filho VJR

Bezerra WGA

Vasconcelos Filho FSL"

Freitas ML"II

Student of the Postgraduate Program in Veterinary Sciences, State University of Ceara - UECE, Brazil

" Student of the Postgraduate Program in physiological Sciences, State University of Ceara - UECE, Brazil

III Undergraduate student at the School of Veterinary Medicine of UECE, Fortaleza, Brazil

Iv Undergraduate student of Biological Sciences, UECE, Fortaleza, Brazil

$\checkmark$ Ph.D. and Professor of the Postgraduate Program in Veterinary Sciences, UECE, Fortaleza, Brazil

vi M.Sc and PhD. Student of the Postgraduate Program in Veterinary Sciences, UECE, Fortaleza, Brazil

\section{Mail Address}

Corresponding author e-mail address Roberta Cristina da Rocha e Silva

Rua 104, n. 176, Conj. Tupã-Mirim II, Bairro

Parque Dois Irmãos - Fortaleza - Ceara,

Brazil - Zip Code 60744-420

Phone/Fax: 55 (84) 991139714

E-mail: robertarochavet@hotmail.com

\section{ABSTRACT}

Salmonellosis is an infection caused by specific or non specific serotypes of the Salmonella genus, responsible for losses in the poultry industry. Fowl typhoid, caused by S. Gallinarum (SG) is important because it causes elevated mortality in adult birds, leading to economic losses in the poultry industry. This study aimed at quantifying the number of viable SG cells in the liver, spleen, lung, cecum, and reproductive tract (ovary and testicles) of experimentally inoculated Japanese quails (Coturnix coturnix), as well as SG shedding in their feces. One hundred and two Japanese quails, with four months of age at the beginning of the experiment, were used. The birds were inoculated with three bacterial cultures containing different concentrations $\left(6 \times 10^{4}\right.$ CFU/0.1 mL, $2 \times 10^{5}$ CFU/ $0.4 \mathrm{~mL}$, or $5 \times 10^{6}$ CFU/0.2mL) of SG resistant to nalidixic acid. On days 1, 4, 7, and 14 after the inoculation (dpi) individual cloacal swabs were collected from six birds per group, which were subsequently sacrificed for organ sampling. The swab samples were streaked directly on plates containing brilliant green agar and nalidixic acid (VBNal). Samples that were negative after 24h, were streaked again. The collected organs were individually macerated and transferred to buffered peptone water at $0.1 \%$. The solutions were immediately diluted serially for CFU counting in VBNal. SG was successfully recovered from one quail, which was inoculated with $2 \times 10^{5} \mathrm{CFU} / 0.4 \mathrm{~mL}$, and from five quails of the group inoculated with $5 \times 10^{6} \mathrm{CFU} / 0.2 \mathrm{~mL}$ inoculum. All of the analyzed cloacal swab samples were negative. Therefore, this study demonstrated it was difficult to isolate SG from the analyzed organs and that it was not possible to recover thepathogen in the cloacal swabs collected from inoculated quails. These results may be explained by the absence of flagella in SG, inducing weak intestinal immune response in the beginning of the infection and preventing its isolation in cloacal swab samples. The low positivity rate of the analyzed organs may be due to the immune status of the euthanized birds, since the SG dissemination in the animal organism occurs mostly close to death, which was observed in the birds found dead during the experiment.

\section{INTRODUCTION}

Salmonella Gallinarum is a pathogenic serotype of Salmonella specific of birds (Setta et al., 2012), and it is characterized by its capacity to grow in systemic locations (Chadfield et al., 2003). This serotype has been isolated from several poultry species, such as chickens, turkeys, pheasants, ducks, guinea fowl, and quails (Shivaprasad, 2000).

Quails have been commercially reared both for egg and meat production (Schmid \& Wechsler, 1997), and its production is currently expanding in Brazil. Some researchers have reported both the presence 
Rocha e Silva RC, Cardoso WM,

Teixeira RSC, Horn RV, Cavalcanti CM,

Almeida CP, Sampaio FP, Albuquerque AH

Lopes ES, Gomes Filho VJR, Bezerra WGA,

Vasconcelos Filho FSL, Freitas ML

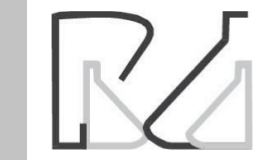

Recovery of Salmonella Gallinarum in the Organs of Experimentally-Inoculated Japanese Quails (Coturnix coturnix) of Salmonella spp. (Bacci et al., 2012) and increasing severity of its infection in quails (Rocha e Silva et al., 2013).

Most avian salmonellosis infections are transmitted through the fecal-oral route. The small intestine is the main site of invasion, which occurs through the gutassociated lymphoid tissues (GALT) and Peyer's patches. The ceca are also colonized, although Salmonella Gallinarum and S. Pullorum are auxotrophic (Chappell et al., 2009).

The adhesion and/or colonization of the avian intestinal tract is initially associated with LPS (lipopolysaccharides), flagella, fimbriae, and some external membrane proteins present in Salmonella spp. (Berndt et al., 2007). Several studies suggest that the presence of flagella is involved in the inflammatory response at the adhesion site and the absence of these structures may avoid the recognition of the pathogenic agent by the immune system. This contributes for the development of systemic infections (Chappell et al., 2009) due to the difficulty in mounting an adequate immune response (Lahiri et al., 2010), culminating in the dissemination of the agent in the environment or in high bird mortality.

The disease caused by SG (fowl typhoid) causes significant economic losses in poultry production (Proux et al., 2002). Due to the expansion of quail rearing in the last few years and the lack of studies on this species, the knowledge of the behavior of the infection of these birds by SG is essential. This study aimed at quantifying the number of viable SG cells in the liver, spleen, lung, cecum, and reproductive tract (ovary or testicle) of experimentally infected Japanese quails (Coturnix coturnix), as well as to evaluate its shedding in the feces.

\section{MATERIAL AND METHODS}

\section{Birds}

In total, 102 (51 female and 51 male) Japanese quails (Coturnix coturnix) were used. Birds were 16 weeks old at the beginning of the experiment, and were randomly assigned to three groups (G1, G2 and G3) with 32 birds each. Six birds were kept as controls. Two quails (one male and one female) were housed per cage $(22 \times 21 \times 16 \mathrm{~cm})$ in batteries placed in a pyramid at the inoculation facilities of the Sector of Ornithological Studies of the State University of Ceará. Water and feed were provided ad libitum. The feed did not contain any antibiotics, and birds were not submitted to vaccination or internal parasite control. House temperature $\left(25.5^{\circ} \mathrm{C}\right.$ ) and photoperiod (16h light/day) were controlled. This project was approved by the local Ethics Committee for the Use of Animals under protocol number 10244779-9/26.

\section{Bacteriological pre-inoculation monitoring}

Before the beginning of the experiment, birds were tested for the presence of Salmonella spp. in order to ensure that they were free from this pathogen. The procedure was performed according to Zancan et al. (2000), with modifications, as follows: individual cloacal swabs impregnated with selenite-cystine and novobiocin $(40 \mu \mathrm{g} / \mathrm{mL})(\mathrm{SCNov})$ were directly streaked onto brilliant green agar plates containing nalidixic acid $(100 \mu \mathrm{g} / \mathrm{mL})(V B N a l)$ and incubated at $37^{\circ} \mathrm{C}$ for 24h. Negative samples for Salmonella spp. were again plated in VBNal and incubated at $37^{\circ} \mathrm{C}$ for $24 \mathrm{~h}$ to confirm the absence of the pathogen in the birds.

The control quails were euthanized and their organs (liver, spleen, lung, cecum, and ovary or testicle) were collected for microbiological examination. The fragments of these organs were macerated, inoculated in $0.1 \%$ buffered peptone water, and incubated at $37^{\circ} \mathrm{C}$ for $24 \mathrm{~h}$. A loopful of each material was then transferred to tubes containing SCNov and incubated at $37^{\circ} \mathrm{C}$ for $24 \mathrm{~h}$. Subsequently, samples were streaked onto plates containing VBNal and incubated at $37^{\circ} \mathrm{C}$ for $24 \mathrm{~h}$.

\section{Inoculum preparation}

Salmonella Gallinarum strain resistant to nalidixic acid (SGNalr) isolated from chickens (Gallus gallus) was used to prepare the inoculum. This strain was donated by the Department of Veterinary Pathology of UNESP, Jaboticabal, Brazil. The inoculum was prepared according to Rocha e Silva et al. (2013) and three distinct concentrations of the inoculum $\left(6 \times 10^{4} \mathrm{CFU} / 0.1 \mathrm{~mL}\right.$, $2 \times 10^{5} \mathrm{CFU} / 0.4 \mathrm{~mL}$ e $5 \times 10^{6} \mathrm{CFU} / 0.2 \mathrm{~mL}$ of Salmonella Gallinarum Nal $/ \mathrm{mL}$ ) were obtained.

\section{Salmonella Gallinarum inoculation}

All birds received $0.1 \mathrm{~mL}$ of the inoculum via gavage, directly in the crop, with the aid of a cannula linked to a $1 \mathrm{~mL}$ syringe. Group 1 birds (G1) received $6 \times 10^{4} \mathrm{CFU} / 0.1 \mathrm{~mL}$, group 2 (G2) received $2 \times 10^{5} \mathrm{CFU} / 0.4 \mathrm{~mL}$, and group $3(\mathrm{G} 3)$ received $5 \times 10^{6}$ CFU/0.2mL.

\section{Post-inoculation monitoring}

During the experimental period, mortality and clinical signs were observed daily. Dead birds were submitted to necropsy for gross evaluation and their organs (liver, spleen, lung, cecum, and reproductive 
Rocha e Silva RC, Cardoso WM

Teixeira RSC, Horn RV, Cavalcanti CM,

Almeida CP, Sampaio FP, Albuquerque AH

Lopes ES, Gomes Filho VJR, Bezerra WGA,

Vasconcelos Filho FSL, Freitas ML

tract) were collected for microbiological analyses according to Rocha e Silva et al.(2013).

Fecal material was collected with the aid of sterile cloacal swabs impregnated in SCNov from euthanized birds on 1, 4, 7, and 14 days post-inoculation (dpi) and directly streaked onto VBNal. Both the broth and the plates were incubated in a bacteriological incubator at $37^{\circ} \mathrm{C}$ for $24 \mathrm{~h}$, after which samples negative for Salmonella spp. were again plated onto VBNal.

On 1, 4, 7, and $14 \mathrm{dpi}$, six birds per group were randomly selected and euthanized by neck dislocation. At necropsy, the spleen, liver, lung, ceca, and reproductive tract (ovary ortesticle) were submitted to gross examination and any changes were duly recorded. Samples of the examined organs were aseptically collected for CFU counting. The microbiological procedure was performed according to Rocha e Silva et al. (2013).
Recovery of Salmonella Gallinarum in the Organs of Experimentally-Inoculated Japanese Quails (Coturnix coturnix)

\section{Results}

The microbiological analyses showed that the cloacal swabs from all quails, as well as organ samples (spleen, liver, lung, ceca and reproductive tract) of the birds euthanized before the beginning of the experiment were negative for Salmonella spp.

It was not possible to countCFU/mL in the organ samples because no colony growth was observed. However, SG was recovered from 4.16\% (1/24)of G1 birds and $20.83 \%$ (5/24) of G2 and G3 birds on 4 dpi and 7 dpi (G3), respectively, after selective enrichment inselenite-cystine broth (Table 1). The only positive G2 quail on 4 dpi presented SG in liver and lung samples. In the $\mathrm{G} 3$ group, on $4 \mathrm{dpi}$, SG was successfully recovered from the liver, spleen, and lung of two quails, and from testicle of one bird. On 7 dpi, SG was isolated from the ovaries of three quails, and from the liver, spleen, and lung samples of one quail.

Table 1 - Isolation of Salmonella Gallinarum fromthe organs of experimentally infected and euthanized Japanese quails (Coturnix coturnix)

Positive birds

\begin{tabular}{|c|c|c|c|c|c|c|c|c|c|c|c|c|c|c|c|c|c|c|c|c|c|c|c|c|}
\hline \multirow{2}{*}{ Group } & \multicolumn{6}{|c|}{ 1st Day } & \multicolumn{6}{|c|}{ 4th Day } & \multicolumn{6}{|c|}{ 7th Day } & \multicolumn{6}{|c|}{ 14th Day } \\
\hline & Bird & $\mathrm{L}$ & $S$ & $C$ & $\operatorname{Lg}$ & RT & Bird & $L$ & $S$ & C & $\operatorname{Lg}$ & RT & Bird & $\mathrm{L}$ & $S$ & C & $\operatorname{Lg}$ & RT & Bird & $\mathrm{L}$ & $S$ & $C$ & $\mathrm{Lg}$ & RT \\
\hline \multirow{6}{*}{ G1 } & 1 & - & - & - & - & - & 7 & - & - & - & - & - & 13 & - & - & - & - & - & 19 & - & - & - & - & - \\
\hline & 2 & - & - & - & - & - & 8 & - & - & - & - & - & 14 & - & - & - & - & - & 20 & - & - & - & - & - \\
\hline & 3 & - & - & - & - & - & 9 & - & - & - & - & - & 15 & - & - & - & - & - & 21 & - & - & - & - & - \\
\hline & 4 & - & - & - & - & - & 10 & - & - & - & - & - & 16 & - & - & - & - & - & 22 & - & - & - & - & - \\
\hline & 5 & - & - & - & - & - & 11 & - & - & - & - & - & 17 & - & - & - & - & - & 23 & - & - & - & - & - \\
\hline & 6 & - & - & - & - & - & 12 & - & - & - & - & - & 18 & - & - & - & - & - & 24 & - & - & - & - & - \\
\hline \multirow{4}{*}{$\mathrm{G} 2$} & 33 & - & - & - & - & - & 39 & - & - & - & - & - & 45 & - & - & - & - & - & 53 & - & - & - & - & - \\
\hline & 34 & - & - & - & - & - & 40 & - & - & - & - & - & 46 & - & - & - & - & - & 55 & - & - & - & - & - \\
\hline & 35 & - & - & - & - & - & 41 & + & - & - & + & - & 47 & - & - & - & - & - & 56 & - & - & - & - & - \\
\hline & 36 & - & - & - & - & - & 42 & - & - & - & - & - & 50 & - & - & - & - & - & 57 & - & - & - & - & - \\
\hline \multirow{8}{*}{ G3 } & 37 & - & - & - & - & - & 43 & - & - & - & - & - & 51 & - & - & - & - & - & 58 & - & - & - & - & - \\
\hline & 38 & - & - & - & - & - & 44 & - & - & - & - & - & 52 & - & - & - & - & - & 60 & - & - & - & - & - \\
\hline & 65 & - & - & - & - & - & 71 & - & - & - & - & - & 78 & - & - & - & - & - & 89 & - & - & - & - & - \\
\hline & 66 & - & - & - & - & - & 72 & - & - & - & - & - & 80 & - & - & - & - & + & 90 & - & - & - & - & - \\
\hline & 67 & - & - & - & - & - & 73 & + & + & - & + & + & 82 & - & - & - & - & - & 91 & - & - & - & - & - \\
\hline & 68 & - & - & - & - & - & 74 & - & - & - & - & - & 83 & - & - & - & - & + & 93 & - & - & - & - & - \\
\hline & 69 & - & - & - & - & - & 76 & + & + & - & + & - & 86 & + & + & - & + & + & 94 & - & - & - & - & - \\
\hline & 70 & - & - & - & - & - & 77 & - & - & - & - & - & 87 & - & - & - & - & - & 95 & - & - & - & - & - \\
\hline
\end{tabular}

L: Liver; S: Spleen; C: Ceca; Lg: Lung; RT: Reproductive Tract 
Rocha e Silva RC, Cardoso WM,

Teixeira RSC, Horn RV, Cavalcanti CM,

Almeida CP, Sampaio FP, Albuquerque AH

Lopes ES, Gomes Filho VJR, Bezerra WGA,

Vasconcelos Filho FSL, Freitas ML

The pathogen was also isolated from several organs of birds that died during the experiment (Table 2). In $\mathrm{G} 1$, one bird presented SG in the liver, spleen, ceca, lung, and testicle, while the other positive bird presented SG in liver and ovary. In G2 birds found dead, all organs were positive (liver, spleen, ceca, lung, and reproductive tract), with the exception of a single bird that presented negative ceca and liver. All organs of the eight $\mathrm{G} 3$ birds that died during the experiment were positive for SG, except for four birds, which presented negative cecum samples.

Table 2 - Isolation of Salmonella Gallinarum from the organs of experimentally infected Japanese quails (Coturnix coturnix) that were found dead during the 14 days of the experiment

\begin{tabular}{|c|c|c|c|c|c|c|c|}
\hline \multirow[t]{2}{*}{ Day } & \multirow[t]{2}{*}{ Group } & \multirow[t]{2}{*}{$N^{\circ}$ Bird } & \multicolumn{5}{|c|}{ Organs } \\
\hline & & & $\mathrm{L}$ & $\mathrm{S}$ & $C$ & $\operatorname{Lg}$ & RT \\
\hline \multirow{5}{*}{$5^{\text {th }} \mathrm{dpi}$} & G1 & 32 & + & + & + & + & + \\
\hline & \multirow{2}{*}{$\mathrm{G} 2$} & 48 & + & + & + & + & + \\
\hline & & 54 & + & + & + & + & + \\
\hline & \multirow{2}{*}{ G3 } & 75 & + & + & + & + & + \\
\hline & & 81 & + & + & + & + & + \\
\hline \multirow{3}{*}{$6^{\text {th }} \mathrm{dpi}$} & \multirow{3}{*}{ G3 } & 79 & + & + & - & + & + \\
\hline & & 84 & + & + & - & + & + \\
\hline & & 88 & + & + & - & + & + \\
\hline \multirow{2}{*}{$7^{\text {th }} \mathrm{dpi}$} & \multirow{2}{*}{ G3 } & 77 & + & + & - & + & + \\
\hline & & 92 & + & + & + & + & + \\
\hline $9^{\text {th }} \mathrm{dpi}$ & G3 & 85 & + & + & + & + & + \\
\hline \multirow{3}{*}{$10^{\text {th }} \mathrm{dpi}$} & G1 & 26 & + & - & - & - & + \\
\hline & \multirow{2}{*}{$\mathrm{G} 2$} & 49 & + & + & + & + & + \\
\hline & & 62 & - & + & - & + & + \\
\hline
\end{tabular}

L: Liver; S: Spleen; C: ceca; Lg: Lung; RT: Reproductive Tract

Birds showed typical fowl typhoid clinical signs, including ruffled feathers, closed eyelids, diarrhea,
Recovery of Salmonella Gallinarum in the Organs of Experimentally-Inoculated Japanese Quails (Coturnix coturnix)

apathy, typically remained quiet in a cage corner, and were frequently found dead after such signs were observed.

Bird mortality began on $5 \mathrm{dpi}$ and was observed until $10 \mathrm{dpi}$. The main macroscopic changes observed in the birds found dead were hepatomegaly and splenomegaly, dilated gallbladder, and hemorrhages in the liver, intestines, and deformed ovarian follicles. On the other hand, the main findings in euthanized birds were hemorrhagic or icteric liver with or without petechiae, dilated gallbladder, splenomegaly, hemorrhagic or icteric spleen with or without petechiae, and hemorrhagic ovarian follicles (Table 3).

Birds that remained alive at the end of the experiment (24 dpi) were euthanized and cloacal swab and organ samples were collected. All samples were negative for SG.

\section{DISCUSSION}

The percentage of SG isolated from the organs of the euthanized quails was much lower when compared with the quails that naturally died during the experiment. This may be explained by the fact that the infectivity of that microorganism, which is enhanced by its high concentration in the tissues when the bird is near death (Buxton \& Davies, 1963).

Salmonella spp. stimulates receptors in the intestinal cells known as toll-like receptor 5 (TLR5). Once activated, these receptors initiate the production of pro-inflammatory interleukins (IL-1, IL-6 and IL-8), which together with macrophages, heterophils, and natural killer cells (NK), are part of the innate immune

Table 3 - Macroscopic changes of the organs of quails experimentally inoculated with Salmonella Gallinarum

\begin{tabular}{|c|c|c|c|c|c|c|c|c|c|c|c|c|c|c|c|c|c|c|c|c|c|}
\hline \multirow{4}{*}{$\begin{array}{l}\text { Organs/ } \\
\text { Lesions }\end{array}$} & \multirow{2}{*}{\multicolumn{6}{|c|}{$\begin{array}{c}\text { Euthanized birds } \\
\text { Experimental groups }\end{array}$}} & \multirow{4}{*}{$\begin{array}{l}\text { Number of } \\
\text { birds }\end{array}$} & \multicolumn{14}{|c|}{ Birds dead due to the disease } \\
\hline & & & & & & & & \multicolumn{13}{|c|}{ Experimental groups } & \multirow{3}{*}{$\begin{array}{c}\text { Total } \\
\text { of } \\
\text { birds }\end{array}$} \\
\hline & \multirow{2}{*}{$\begin{array}{l}\mathrm{G} 2 \\
41 \\
\end{array}$} & \multicolumn{5}{|c|}{ G3 } & & \multicolumn{2}{|c|}{ G1 } & \multicolumn{4}{|c|}{$\mathrm{G} 2$} & \multicolumn{7}{|c|}{ G3 } & \\
\hline & & 73 & 75 & 79 & 82 & 86 & & 26 & 32 & 48 & 49 & 54 & 62 & 77 & 79 & 81 & 84 & 85 & 88 & 92 & \\
\hline \multicolumn{22}{|l|}{ Liver } \\
\hline Hypertrophy & & & & & & $x$ & 01 & & $x$ & & & $\mathrm{x}$ & & $x$ & $x$ & $\mathrm{x}$ & $x$ & $x$ & & & 07 \\
\hline Hemorrhage & $x$ & & $x$ & & & & 02 & & & $x$ & & & & & & $x$ & & $x$ & & & 03 \\
\hline Necrosis & & & & & & & 00 & $x$ & & & & $\mathrm{x}$ & & $\mathrm{x}$ & $x$ & & $\mathrm{x}$ & $\mathrm{x}$ & & & 06 \\
\hline Icterus & & $x$ & & & $x$ & & 02 & & & & & & & & & & & & & & 00 \\
\hline Gallbladder & & & & & & & & $\mathrm{x}$ & & & & & & & & & & & & & 01 \\
\hline \multicolumn{22}{|l|}{ Spleen } \\
\hline Hypertrophy & $x$ & $x$ & & & & $x$ & 03 & $x$ & $x$ & & $x$ & & $x$ & & $\mathrm{x}$ & $x$ & $x$ & $x$ & $\mathrm{x}$ & $x$ & 10 \\
\hline Pale & & & & $x$ & & & 01 & & & & & & & & & & & & & & 00 \\
\hline \multicolumn{22}{|l|}{ Ovary } \\
\hline Hemorrhage & & & & $x$ & & $x$ & 02 & & & & & & $x$ & & & & $x$ & & & $x$ & 03 \\
\hline Atrophy & & & & & & $x$ & 01 & $x$ & & & & & & & & & $x$ & & $x$ & & 03 \\
\hline \multicolumn{22}{|l|}{ Uterus } \\
\hline Dark & & & & & & $x$ & 01 & & & & & & & & & & & & & & 00 \\
\hline
\end{tabular}


Rocha e Silva RC, Cardoso WM,

Teixeira RSC, Horn RV, Cavalcanti CM,

Almeida CP, Sampaio FP, Albuquerque AH

Lopes ES, Gomes Filho VJR, Bezerra WGA,

Vasconcelos Filho FSL, Freitas ML

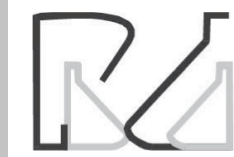

Recovery of Salmonella Gallinarum in the Organs of Experimentally-Inoculated Japanese Quails (Coturnix coturnix)

study, such as closed eyes (Freitas Neto et al., 2007), ruffled feathers and diarrhea (Alvarez et al., 2003), and apathy (Garcia et al., 2010). Also, some of the gross changes observed during necropsy were consistent with those found in chickens, including hepatomegaly and hemorrhagic ovarian follicles (Berchieri et al., 2000), as well as deformed and congested liver (Hossain \& Islam, 2004)

\section{CONCLUSION}

Salmonella Gallinarum was not recovered from any of the evaluated organs of the experimentally infected quails. However, it was successfully quantified in birds that died of the disease during the experimental period. Therefore, we suggest that the immune system of the birds that survived may have cleared the infection, hindering the recovery of the pathogen in birds that did not die of the infection. It is difficult to recover SG in fecal samples of experimentally inoculated quails, which suggests that infected quails that do not present clinical signs do not contribute for the horizontal transmission of the pathogen via feces.

\section{ACKNOWLEDGEMENTS}

The authors are grateful to CAPES for the financial support and to the Laboratory of Ornithological Studies (LABEO/FAVET/UECE) for their support to this study.

\section{REFERENCES}

Alvarez MT, Ledesma N, Téllez G, Molinari JL, Tato P. Comparison of the immune responses against Salmonella enterica serovar Gallinarum infection between naked neck chickens and a commercial chicken line. Avian Pathology 2003;32(2):193-203

Bacci C, Boni E, Alpigiani I, Lanzoni E, Bonardi S,Brindani F. Phenotypic and genotypic features of antibiotic resistance in Salmonella enterica isolated from chicken meat and chicken and quail carcasses. International Journal of Food Microbiology 2012;160(1):16-23

Barrow PA, Lovell MA, Murphy CK, Page K. Salmonella infection in a commercial line of ducks; Experimental studies on virulence, intestinal colonization and immune protection. Epidemiology and Infection $1999 ; 123(1): 121 \pm 132$

Berchieri Jr A, Freitas Neto OC. Salmoneloses. In: Berchieri JR A, Silva EN Di Fábio J, Sesti L, Zuanaze MAF, editors. Doença das aves. São Paulo: FACTA; 2009. p.435-454.

Berchieri JrA, Oliveira GH, Pinheiro LAS, Barrow PA. Experimental Salmonella Gallinarum infection in light laying hen lines. Brazilian Journal of Microbiology 2000;31(1):50-52.

Berchieri Jr A, Murphy A, Marston K, Barrow PA. Observations on the persistence and vertical transmission of Salmonella enterica serovars Gallinarum and Pullorum in chickens: effect of bacterial and host genetic background. Avian Pathology 2001;30(3):221-231. 
Rocha e Silva RC, Cardoso WM

Teixeira RSC, Horn RV, Cavalcanti CM,

Almeida CP, Sampaio FP, Albuquerque AH

Lopes ES, Gomes Filho VJR, Bezerra WGA,

Vasconcelos Filho FSL, Freitas ML
Recovery of Salmonella Gallinarum in the Organs of Experimentally-Inoculated Japanese Quails (Coturnix coturnix)

Typhimurium, Salmonella Enteritidis and Salmonella Gallinarum. Microbiology 2000;146(12):3217-3226.

Lahiri A, Lahiri A, lyer N, Das P, Chakravortty D. Visiting the cell biology of Salmonella infection. Microbes and Infection 2010;12(11):809-818.

Proux K, Humbert F, Jouy E, Houdayer C, Lalande F, Oger A, Salvat G. Improvements required for the detection of Salmonella Pullorum and Gallinarum. The Canadian Journal of Veterinary Research 2002;66(3):151-157.

Rocha e Silva RC, Cardoso WM, Teixeira RSC, Albuquerque ÁH, Vasconcelos RH, Cavalcanti CM, Lopes ES, Gomes Filho VJR. Salmonella Gallinarum virulence in experimentally-infected Japanese quails (Coturnix japonica). Brazilian Journal of Poultry Science 2013;15(1):233-238.

Setta AM, Barrow PA, Kaiser P, Jones MA. Early immune dynamics following infection with Salmonella enterica serovars Enteritidis, Infantis, Pullorum and Gallinarum: cytokine and chemokine gene expression profile and cellular changes of chicken cecal tonsils. Comparative Immunology, Microbiology and Infectious Diseases 2012;35(5):397-410.

Shivaprasad HI. Fowl typhoid and pullorum disease. Office International des Epizooties, Scientific and Technical Review 2000;19(2):405-424

Schmid I, Wechsler B.Behaviour of Japanese quail (Coturnixjaponica) kept in semi-natural aviaries. Applied Animal Behaviour Science 1997;55(12):103-112

Wigley P, Hulme SD, Bumstead N, Barrow PA. In vivo and in vitro studies of genetic resistance to systemic salmonellosis in the chicken encoded by the SAL1 locus. Microbes Infection 2002;4(11):1111-1120.

Wigley P, Hulme S, Powers C, Beal R, Smith A, Barrow P. Oral infection with the Salmonella enterica serovar Gallinarum $9 R$ attenuated live vaccine as a model to characterise immunity to fowl typhoid in the chicken. BMC Veterinary Research 2005;1(2):1-6.

Zancan FT, Berchieri J A, Fernandes AS, Gama NMSQ. Salmonella investigation in transport boxes of day-old birds. Brazilian Journal of Microbiology 2000;31(3):230-232. 